\title{
Effects of Migration of Farmers on Sustainable Livelihood in Nigeria
}

\author{
${ }^{1}$ Ibrahim Salihu Koko Phd, ${ }^{2}$ Danjuma Abdullahi Phd \\ ${ }^{1}$ Department of Agriculture and General Technology College of AgricultureZuru Kebbi state \\ ${ }^{2}$ College of law, government and international studies Universiti Utara Malaysia
}

\begin{abstract}
The paper seek to investigate the effects of migration of rural famers from periphery to urban centres in Nigeria in search for greener pasture, despite the fact that $75 \%$ of Nigerians are farmers $50 \%$ of its population are sleeping in hunger making the live of rural farmers unstable and constituting reasons for the influx which have various effects on rural and urban settlements in Nigeria. The methodology adopted was descriptive using secondary data and interview with rural farmers and the findings revealed that the migration of farmers has course clashes between the immigrants and host communities as a result of succession for land and increase in the rate of crimes such as armed robbery, petty thieving, kidnapping and emergence of such groups such as Boko Haram. Therefore the paper suggests that government should provide infrastructural facilities and empower the rural farmers to reduce the rate of migration.
\end{abstract}

Key words: Sustainability, Farmers, Migration, Government

\section{Introduction}

Agriculture is the main stay of the livelihood of the people of Nigeria powered by energetic and able bodied rural dwellers, present productive capacity could be hampered by influx of rural farmer to urban areas of Nigeria taking along with them vast amount of Agricultural skills to other areas of the Federation thus starving the younger generations of adequate agricultural knowledge to cope with day to day living. Various factors have contributed to account for this influx. Apart from the risks and uncertainties associated with rural urban migration, migrant at final destination appeared to be vulnerable to many factors such as unemployment thereby adding to already teaming population of the unemployed in the urban areas. The danger posed by this army of unemployed youths has been a serious concern to security in urban areas (DeHaan, 1999). Through rural urban migration interaction takes place which sometimes places the rural areas at a greater disadvantage. The bulk of urban wastes are deposited at the urban boundary, such environmentally unfriendly materials no doubt have some negative effect on the farmers health and his environment. Through rural urban migration young girls are taking to the cities inform of marriage, however, when the marriage collapses the rural girl having tested city life will not return to her rural domicile and the presence of such young females in urban areas at such a vulnerable stage could no doubt increase the chances of spread of sexually transmitted diseases (DeHaan, 1999). Migration pattern in Nigeria in so many occasions obeys the seasonal laws with bulk of it occurring during the dry season (Daily News, 2003). This no doubt hampers rescuing ability in times of emergency such as bush fire outbreaks in rural areas, because most able body's men have left. The problem is more compounded where the seasonal migrant has ties at the final destination which could result into non return migration further putting parents and family into destitute. Rural urban migration has both positive and negative consequences on

Agricultural potential/livelihoods of both the original domicile and the final destination (Deshinkar, 2003). Therefore investigating the effects of rural farmer migration on sustainable livelihoods in Nigeria will be the focal point of this research work.

\section{Agriculture and sustainable livelihood in Nigeria}

During the 1960s agriculture constitute the mainstay economic activities of Nigerians which contributed more than sixty 60\% to the Gross Domestic Product. The country was among the leading producers of cash and food crops such as Cocoa, Groundnut, Cotton, Rubber, Palm oil and hide and skin. The popular groundnut pyramid in the Northern Nigeria was a clear picture.

With the discovery of oil in 1970s agriculture witness declined, although past administration had tried to promote agriculture through launching of programmes such as :-

$>$ Operation feed the nation in 1976

$>$ Green revolution 1979-83

> Directorate of foods, roads and rural infrastructure 1986-1993

$>$ Back to land 1984-1985

$>$ Nigerian land development authority1991-1999

$>$ Better life for rural women 


\begin{tabular}{ll}
\hline & Family support programme \\
$>$ & Poverty Alleviation 1999-2002 \\
$>$ & Poverty eradication 2003- date \\
$>$ & Millennium development goals
\end{tabular}

\section{Causes of Migration}

EMPLOYMENT OPPORTUNITIES: According to Tacoli (1998) urban areas are viewed by rural dwellers with the image of places full of economic and material gain thereby influencing migration decision. According to Datta (2004) in one survey carried out in West Bengal 80\% of the respondents migrants agreed that their reason for migration was in terms of job opportunities prevailing in West Bengal attracted them to the area.

EDUCATION: Kline (2003) stated that Mejia, Pizurki, and Royston (1979) reported that migration is induced due to interplay of various forces at both sending and the receiving areas, and most of these forces are political, social, economic, legal, historical, cultural and educational. Kline (2003) further stated that some nurses migrate in order to look for professional development that cannot be attained in their current job or area of domicile suggesting that education is a pull factor of migration. Furthermore Kline (2003) stated that some advanced countries like Japan, working visas are limited to Academicians, Technology expert and professional Journalist further demonstrating that education is a pull factor of migration. According to Afolayan et al (2008) the search for Islamic education has made a tremendous contribution towards international migration in Northern Nigeria where scores of men and children travel far away from their places of origin not minding the border in search of Islamic education. Afolayan et al (2008) further stated that British colonial administration in Nigeria had open a way for Nigerian student to be registered for higher education in various institution of higher learning in the United Kingdom and by 1984 about 10,000 Nigerians many highly skilled were already residing in the United States of America.Choices, develop skills and experience, participate socially and so on). Ellis (2000) further stated that "strictly, capabilities refer to the set of alternative beings and doings that a person can achieve with his or her economic, social and personal characteristics". According to Ellis (2000) definition of capabilities as livelihood components have become somewhat confusing due to their overlapping nature with assets and it is apparent that capabilities influence and are being influenced by personal and household livelihood strategies. According to Ellis (2000) assets contained in livelihood definition are comprised of the various forms of capitals earlier discussed as well as claims and access. According to De Haan (2002) through migration, the capabilities of individuals are improved in view of the fact that the migrant acquires some form of education and brings back home new ideas and new skills which could in some circumstances improve productivity in Agriculture. De Haan (2000) further stated that migrants invest in education in the community as well as in the communal activities that help build schools, through remittances after their return.

(1) Creation of Working Days: This is the ability of a particular combination of livelihood strategies to develop gainful employment for a given period of the year which could be off -farm, part of a wage labour system or through subsistence type of production At least 200 days is widely accepted to be minimum for a sustained livelihood.

(2) Vulnerability and Resilience: this entails the ability or mobility to recover from shocks in form of adaptation and coping. Adaptation entails longer term shifts in livelihood strategies while coping entails temporary adjustments in the face of change. Both are important components of livelihood and where they are lacking, vulnerability occurs resulting in an unsustainable livelihood. A historical record of coping with shocks and stresses is important when evaluating and assessing resilience.

(3) Natural Resource Base Sustainability: Since most rural people depend upon some form of natural resources for livelihood, the sustainability of natural resource use depends on being at a level where it can recover from shocks and stress without threatening livelihoods. It is a difficult task to measure natural resource depletion or accumulation e.g. measuring soil fertility levels or vegetation cover and to link it with livelihood needs or to assess whether natural resource depletion has resulted in a permanent decline in useful products or services.

(4) Poverty Reduction: this is a key criterion upon which livelihood is assessed. There are various measures to obtain absolute poverty line such as measuring of income or consumption level while relative poverty is assessed using Gini coefficient measures.

Dehaan (2000) states that poverty is not the main cause of migration and poverty. Migration links are very complex affairs and the contribution of migration towards reducing poverty is difficult to assess. On the role of migration in reducing poverty De Haan (2000) notes that:

(1) Migrants do help to increase the welfare of areas of destination by contributing to the economic development of the host society.

2. Cheap migrant labour ensures a boost in the economy of the host country while the country of origin suffers decline in productivity through loss of young wage-earning men. 


\section{Livelihood Strategies}

Within the sustainable livelihood framework there are three broad categories of livelihood strategies namely: Agricultural intensification/extension, livelihood diversification and migration (Scoones, 1998). Further more, Scoones (1998) stated that identifying the various capitals that need to be combined in order to achieve a sustained livelihood is the back bone of process analysis which is very critical in the pursuit of different livelihood strategies. According to Scoones (1998) identifying the connections between the various processes such as migration and diversification as well as understanding the outcomes of combining the various processes to achieve sustainable livelihood, requires splitting and explaining of each of the three broad categories of livelihood strategies as given below.

\section{(I) Livelihood Diversification}

"Rural livelihood diversification is defined as the process by which rural households construct an increasingly diverse portfolio of activities and assets in order to survive and to improve their standard of living" (Scoones 1998). Furthermore Scoones (1998) noted that diversification involves developing a wide income earning portfolio to cover all types of shocks or stresses jointly, or alternatively? The strategy may involve focussing on developing responses to handle a particular type of common shock or stress through well developed coping mechanisms (Fig 2).

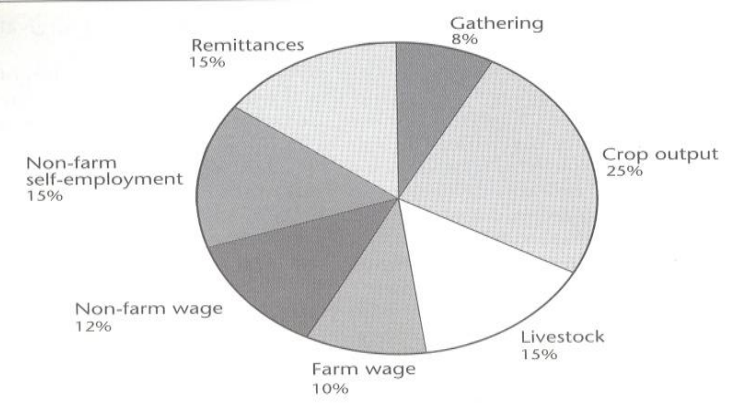

Fig 2: Sources of livelihood diversification Source: Ellis (2000)

\section{(II) Agricultural Intensification/Extensification}

Intensification aims at maximizing the use of the little available farm land with new inputs and technology in order to achieve high production while extensification aims at extending the size of existing farms in order to achieve high production.

\section{(III) Migration}

Distinguishing the outcome between the different migration causes (such as voluntary and involuntary migration), effects (such as reinvestment in agriculture, enterprise or direct consumption by migrant household) and movement patterns (to and from for different destinations).

\section{Incomes as Components of Livelihood strategies in Nigeria}

The National office of statistics (2012) revealed that 112 million Nigerians lives below poverty line earning less than one dollar per day. Also Ellis (2000)opined that income and livelihood do not mean the same thing but are inter- related. Ellis (2000) further defined income as "both cash and in kind contributions to the material welfare of the individual or household deriving from the set of livelihood activities in which household members are engaged. Depending upon income source, resources required to obtain them, their seasonality and assets and skills required to obtain the income; Ellis (2000) categorised income as follows:

(I) Farm Income: this refers to those types of income generated based on farming disregarding whether the farm land is owner occupied or shared tenancy. Farming should include rising of livestock as well as crop both of which income is derived. Farm income also includes consumption in-kind of farm output as well as cash obtained through sales of farm produce.

(II) Off- farm Income: refers to income generated as the result of exchange of labour within agriculture. Such labour payments could be in kind where by harvest is shared. Non kind of farm income could be as the result of sales of resources such as firewood, charcoal and home building materials.

(III) Non Farm Income: this refers to income generated as the result of non agricultural activities. Such non farm incomes include: wage salary received from rural employment, nonfarm rural self employment or business income, rental income from property owned, urban-rural remittances generated from international migrant family members and other urban to rural transfer of cash such as retiree pensions. For details see Fig 3. 
Effects Of Migration Of Farmers On Sustainable Livelihood In Nigeria

Agric contribution to GDP\% in Nigeria from 2006-2010

\begin{tabular}{|l|l|l|}
\hline Year & Contribution to GDP & Sectorial growth \\
\hline 2006 & 41.72 & 7.40 \\
\hline 2007 & 42.01 & 7.19 \\
\hline 2008 & 42.13 & 6.27 \\
\hline 2009 & 41.70 & 5.88 \\
\hline 2010 & 40.84 & 5.64 \\
\hline
\end{tabular}

Adapted from National Bureau of Statistics 2010

From the table above, it is clear that from 2006 GDP contribution of agriculture to growth of economy of Nigeria was 41.72 in 2006, to 42.01 in 2007 and to 40.84 in 2010. Also sectorial growth was 7.40, decreased to 7.1 in 2007 , to 6.27 in 2008 , to 5.88 in 2009 and finally to 5.64 in 2010.

Quarterly growth of Agriculture in 2010

\begin{tabular}{|l|l|l|}
\hline Quarter & Growth & Contribution \\
\hline First Quarter & 5.43 & 35.68 \\
\hline Second Quarter & 5.84 & 42.32 \\
\hline Third Quarter & 5.68 & 44.30 \\
\hline Fourth Quarter & 5.56 & 40.11 \\
\hline Annual & 5.64 & 40.84 \\
\hline
\end{tabular}

Adapted from National Bureau of Statistics 2010

From the table above the quarterly growth of agriculture in 2010 was 5.43 and increased to 5.56 in fourth quarter. While contribution was 35.68 and increased to 40.11 in the fourth quarter.

\section{Effects of Migration on sustainable livelihood}

Increase in poverty: One of the results of migration of farmers from rural to urban on sustainable livelihood was the increase in poverty. Youths left their villages with the intention of finding work at towns and urban centres but unfortunately many of them ended up without any work to do which is constituting problem to their livelihood some of them instead of coming back to the village resort to peti- crime and stealing in order to survive. Low enrolment in our educational institution: The average net primary school attendance rate of $60 \%$ and secondary rate of 50\%. Rural population also suffer inordinately from a lack of education with rural primary enrolment nearly $20 \%$ lower than urban enrolment (UNICEF 2008).

Health wise, it has also contributed to the spread of HIV related diseases in urban centres which is affecting the labour force in Nigeria. Most of the HIV related diseases career are the youths between the ages of 15-35 as a result it have a very great effects on the labour force. In spite of the large arable lands the country has for agricultural activities, the poor state of its agricultural sector has led the country as a net importer of agricultural goods. Nigeria importation of food rise to 1.8 million tonnes of rice per year (FAO, June 2010). This make the country vulnerable to international fluctuation of food prices.

The Migration also led to a lot of crises such as armed robbery, Boko Haram that is creating problems of insecurity of lives and properties in the country which have effect on foreign direct investment in Nigeria. The crisis led to the decrease in foreign direct investment in Nigeria by about $14 \%$ from 2008-2010

Unemployment has also increase due to shift from agriculture to wage labour in the urban centres. Many youths left the village in an attempt to find jobs in the urban centres but many could not find job and constitute malice to their host communities. Food account for a considerable amount of household consumption in Nigeria $(64 \%$ in rural areas and 62.6\%) in urban areas. Therefore rising cost of food compounded by declining incomes has lead to substantial challenges with regard to food security.

\section{Conclusion}

Conclusively, the paper look at the effects of migration of rural famers on sustainable lively hood in Nigeria, because despite the role of government which aim at reducing poverty and enhancement of rural development in Nigeria the problems of rural men are enormous which led to migration in search for the means of livelihood and constitute problems both to the rural and urban centres such as neglect of agricultural sector, increase in crime wave such as armed robbery, prostitution, emergence of Militancy such as Boko Haram and Niger Delta crises, kidnapping which is scaring the foreign investors away from the country. 


\section{Recommendations}

The following are some of the recommendations with the hope that if put in place it will help in solving the problems of rural -urban migration as it affect their sustainability in Nigeria

Government should provide infrastructural facilities to rural areas in Nigeria in order to prevent the rate of migration to the urban centres.

Also government should try as a matter of urgency to provide quality education to the masses, the type of education that will make them becoming self reliant instead of dwelling around in search for greener pasture. Government should also provide good atmosphere in order to encourage foreigners to come to Nigeria and invest into the economy that will help in addressing unemployment in Nigeria.

In addition, government should come out with viable programmes and ensure the sustainability of it in order to reduce rate of unemployment among the village youths in Nigeria. Finally, government should try and provide rural farmers with farm inputs such as tractors, fertilizers, irrigation facilities in so as to enable them yield much output and reduce the rate of migration.

\section{Reference:}

[1] Afolayan, A.A; Ikwuyatum, G.O and Abejide, O. (2008) "Dynamics of International Migration in Nigeria: A Review of Literature", Country paper: Nigeria, prepared as part of the African Perspectives on Human Mobility Programme. 29-31

[2] Daily News (2003): Nigeria People, Population and Settlement-Kebbi State. Pp1-2 Available at http://www.onlinenigeria.com/links/kebbiadv.asp?blurb=300.

[3] Datta P. (2004) "Push-Pull Factors of Undocumented Migration from Bangladesh to West Bengal: A Perception Study" The Qualitative Report, 9 (2) 350-352. Extracted from

[4] De Haan, A. (1999) "Livelihood and Poverty: the role of migration A critical review of the migration literature", A paper for th coming in journal of Development studies.

[5] De Haan, A. (2000) "migrants, livelihoods and rights: the relevance of migration in development policies" Social development working paper, (4), Pp1-27. Extracted from

[6] http://www.radiodpb.org/RelatedNotes/Arjan\%20de\%20Maan\%20-\%20Migrants,\%20Livelihoods\%20and\%20rights$\% 20$ the $\% 20$ relevance\%20of\%20migration\%20in\%20development\%20policies.pdf on 05/ 05/2008 can't be forthcoming now get the reference

[7] Deshingkar, P. (2003) "Seasonal migration for livelihoods in India: coping, Accumulation and Exclusion" A working paper, Overseas Development Institute, London, (220), Pp 1-29

[8] Ellis, Frank (2000) rural livelihoods and diversity in Developing Countries Oxford University press, oxford pp 7-23

[9] Kline D.S. (2003) "Push and Pull Factors in International Nurse Migration", Journal of Nursing Scholarship, 35 (2) $108-110$ Extracted from

[10] Scoones, I. (1998) "Sustainable Livelihoods a frame work for analysis", IDS working paper 72 build on discursion held at 1997 during the preparation for field ---- phase of the DFID ESCOR.

[11] Tacoli, C. (1988) "Rural-urban interactions: a guide to literature", journal of environment and urbanisation, 10 (1) Pp 1-23 